\title{
Influence of production systems and sex on nutritional value and meat quality of native Malawian Muscovy ducks
}

\author{
J. Tanganyika ${ }^{1,2 \#}$ \& E.C. Webb ${ }^{1}$ \\ ${ }^{1}$ Department of Animal and Wildlife Sciences, Faculty of Natural and Agricultural Sciences, University of Pretoria, Private \\ Bag X20, Hatfield 0028, South Africa \\ ${ }^{2}$ Animal Science Department, Faculty of Agriculture, Bunda College, Lilongwe University of Agriculture and Natural \\ Resources, P. O. Box 219, Lilongwe, Malawi
}

(Received 14 May 2019; Accepted 21 September 2019; First published online 31 January 2020)

\begin{abstract}
This study was conducted to assess effects of production systems and sex on nutritional value and meat quality of native Malawian Muscovy ducks. One hundred twenty ducks were randomly assigned to either an intensive (IS), duck-rice integration (DR) or free-range (FR) production system. A starter ration containing $20 \%$ crude protein and a finisher containing $17 \%$ crude protein were fed to ducks in IS (1 to 4 weeks), and provided as a supplement to ducks in DR and FR (5 to 10 weeks). Feed and water were offered ad libitum. At 10 weeks of age, 16 ducks per treatment were selected randomly, slaughtered and chilled at 4 ${ }^{\circ} \mathrm{C}$ for 24 hours. Carcass temperature, $\mathrm{pH}$ and meat colour were measured at $45 \mathrm{~min}$, and at 3, 6, 12 and 24 hours post mortem. Tenderness, cooking loss, proximate and mineral composition were determined 24 hours post mortem. Production system and sex had no effect on carcass temperature, $\mathrm{pH}$ and proximate composition of duck breast meat. However, production system affected tenderness and mineral composition of the meat and sex influenced moisture and tenderness. Males were moister and had less tender meat than females. Carcasses from ducks in the FR system contained more zinc, copper, manganese, and potassium, but less iron while those in IS had the lowest mineral content of the three production systems. Thus, DR can be adopted to improve the current FR system of native Malawian Muscovy duck production with supplementation to produce duck with acceptable mineral composition and better meat quality.
\end{abstract}

Keywords: cooking loss, meat colour, mineral, proximate composition

\#Corresponding author: jtanganyika@gmail.com

\section{Introduction}

The duck population is increasing in Malawi with about 2390304 ducks, which represent about 2.1\% of the total poultry population (Department of Animal Health and Livestock Development, 2017). Duck meat is the third most widely produced poultry meat in the world after chicken and turkey (Uhlírov et al., 2018). Duck meat comprises 2900 tonnes of meat production in Malawi, which represents $0.4 \%$ of its total meat production (Department of Animal Health and Livestock Development, 2017). The most common production system of ducks is the traditional free-range system (FAO, 2008; Gondwe, 2004) in which ducks are mostly kept together with indigenous chickens with limited provision of supplementary feed, especially during periods of feed shortage and reduced scavenging (FAO, 2016). It is estimated that the consumption of meat in Malawi was $8.3 \mathrm{~kg}$ per person per year in 2013, which is below the $10 \mathrm{~kg}$ norm (FAO, 2013). This level of meat consumption is considered insufficient, since such low intake often leads to under-nourishment and malnutrition. Meat from conventional livestock species such as goats, cattle, pigs, sheep and chicken is not sufficient, and ducks could be an alternative since they are hardier and more tolerant of viral diseases than chickens, survive in free-range environments, and contribute significantly to the food security and protein intake of people in rural communities (FAO, 2017).

According to Ramadhan et al. (2010), the diets fed to ducks affect their chemical composition. Duck meat has low cholesterol and high unsaturated fatty acid, and is recognised as a healthy alternative source of animal protein, which is gaining popularity (Hong et al., 2014). Nowadays, consumers are health conscious and prefer food and meat products that are low in fat, cholesterol and caloric content (Yang et al., 
2007). At the same time, consumers believe that poultry that is raised in confined systems is prone to stress, resulting in negative physiological and behavioural responses and poor performance (Li et al., 2017). Apart from diet, meat quality attributes such as carcass temperature and $\mathrm{pH}$, meat colour, cooking loss, proximate and mineral composition and tenderness are affected by age, genetics, species, sex, slaughter method, and handling methods such as catching, grading, transportation, unloading and shackling of birds.

Consumers of duck meat in Malawi are unaffected by cultural or religious taboos, so duck meat provides a huge opportunity for sustainable food security. However, duck meat production is still low owing to a lack of knowledge of proper management systems, the preference for chicken production by many smallholder farmers (Njunga et al., 2010), and the absence of health and extension services. So far, no studies have been conducted in Malawi to assess the nutritive value and quality of duck meat raised in different production systems, hence, the current study.

\section{Materials and Methods}

The study was conducted at Bunda College of Lilongwe University of Agriculture and Natural Resources (LUANAR) in Malawi, with ethics approval by the Animal Ethics Committee of the University of Pretoria (EC 032-17). A total of 120 one-week-old ducklings were raised in three production systems, namely intensive (IS), duck-rice integration (DR) and free-range (FR) in a $3 \times 2$ (production $x$ sex) factorial experiment in a completely randomised block design. According to NRC (1994), a starter ration (20\% CP, 14 weeks) and finisher (17\% CP, 5-10 weeks) were given as complete feed to ducks in IS, and as a supplement to ducks in the DR and FR systems. The feed ingredients for the ration were maize meal, maize bran, soybean meal, fish meal, salt and mineral/vitamin premixes (Table 1). The main feed ingredients, namely maize meal, maize bran, soybean and fish meal, were subjected to chemical analysis (AOAC International, 2005) and Pearson square was used to formulate the ration (Table 1).

Table 1 Feed ingredients and chemical composition of the ration used in duck feeding systems, $100 \mathrm{~kg}$ bag

\begin{tabular}{lcc}
\hline Ingredient & Starter $(\mathrm{kg})$ & Finisher $(\mathrm{kg})$ \\
\hline Maize & 22.65 & 25.51 \\
Maize bran & 45.30 & 51.01 \\
Soybeans roast / full fat & 19.77 & 14.05 \\
Fishmeal & 9.89 & 7.03 \\
Salt & 0.25 & 0.25 \\
Vitamin and mineral premix & 0.25 & 0.25 \\
Mono calcium phosphate (MCP) & 1.00 & 1.00 \\
Agricultural lime & 0.80 & 0.80 \\
DL-Methionine & 0.10 & 0.10 \\
Chemical composition (dry matter) & & \\
Crude protein (g/kg) & 199.5 & 169.6 \\
Digestible energy Mcal/kg) & 3.476 & 3.420 \\
Metabolizable energy (Mcal/kg) & 3.0 & 3.0 \\
Crude fibre (g/kg) & 39.0 & 39.2 \\
Calcium (g/kg) & 6.5 & 6.1 \\
Available phosphorus (g/kg) & 8.0 & 7.6 \\
Methionine (g/kg) & 4.0 & 3.6 \\
Lysine (g/kg) & 10.0 & 8.1 \\
\hline
\end{tabular}

*Each $2.5 \mathrm{~kg}$ contains vitamin A: $10000000 \mathrm{IU}$; vitamin D3: 3000000 IU; vitamin E: 15000 IU; vitamin K: 1000 mg; thiamine (B1): $1000 \mathrm{mg}$; ribfolavin (B2): 5000 mg; pyridoxine (B6): 1000 mg; vitamin B12: 10000 mcg; niacin: 32000 mg; pantothenic acid: $16000 \mathrm{mg}$; folic acid: $1000 \mathrm{mg}$; biotin: $100 \mathrm{mg}$; choline chloride: $200000 \mathrm{mg}$; antioxidant: 6000 mg; manganese: 80000 mg; zinc: 70000 mg; iron: 30000 mg; copper: 10000 mg; iodine: 1000 mg; selenium: 100 mg; cobalt: $500 \mathrm{mg}$ 
At the end of the experiment, feed was withdrawn 12 hours before slaughter (Kwon et al., 2014) and 48 ducks (16 from each treatment) were selected randomly, slaughtered and kept in the chiller at $4{ }^{\circ} \mathrm{C}$ for 24 hrs for further analysis such as cooking loss, tenderness, and proximate and mineral composition. Duck breasts (Pectoralis muscle) were analysed for meat quality attributes since the breast is one of the crucial parts for the culinary value and technological properties of duck meat (Witkiewicz, 2000; Wołoszyn et al., 2002; Galal et al., 2011), the other part being the thigh muscle.

Carcass $\mathrm{pH}$ and temperature profiles were measured by a pH meter (Kim et al., 2012) at 45 minutes, 3 hours, 6 hours, 12 hours, and 24 hours post mortem and recorded in tripplicate (Ronald et al., 2006). The pH meter, which also measured carcass temperature, was dipped into the pectoralis muscle to at least a depth of $2 \mathrm{~cm}$ at a similar place in each pectoralis muscle.

Meat colour was determined by means of a Konica Minolta CR400 chroma meter (Mussah \& Phoya, 2017), whereby $30 \times 30 \mathrm{~mm}$ samples from the pectoralis muscle were prepared, labelled and used to capture colour scores of lightness $\left(L^{*}\right)$, redness $\left(a^{*}\right)$, and yellowness $\left(b^{*}\right)$. Three random readings were taken from each meat sample from different angles.

Meat tenderness was determined by an Instron universal testing machine (TA.XT plus texture analyser). The machine was calibrated to have a crosshead speed of $100 \mathrm{~mm} / \mathrm{min}$ at the full-scale load of 50 $\mathrm{kg}(500 \mathrm{~N})$. From each pectoralis muscle, a sample of $5 \times 40 \mathrm{~mm}\left(\mathrm{ca} .2 .0 \mathrm{~cm}^{2}\right)$ cross section was cut for shear force measurement (Ali et al., 2007). The meat samples were placed at right angles to a plunger-type blade. Nine samples from each pectoralis muscle were tested and readings recorded. Data were collected and analysed based on the shear force values to obtain the maximum force required to shear through each muscle sample.

Cooking loss was determined by cutting and weighing $20 \mathrm{~g}$ of the pectoralis muscle. The meat samples were put in the plastic tubes and boiled in a water bath to an internal temperature of $90{ }^{\circ} \mathrm{C}$ for 30 minutes. After boiling, the samples were surface dried, and weighed. Cooking loss was determined by expressing weight of cooked sample (B) as a percentage of the precooked sample (A):

$$
\text { Cooking loss }(\%)=[(\mathrm{A}-\mathrm{B}) /(\mathrm{A})] \times 100(\text { Khan et al., 2016) }
$$

Proximate composition was determined after removing the skin and external fat from the breast (pectoralis major) meats according to procedures of the AOAC International (2005). Total fat was determined by the AOCS standard procedure Am 5-04 (Ankom, 2001) in which the Ankom XT10 extraction system was used. Micro-minerals that were analysed in the duck meat were potassium $(\mathrm{K})$, zinc $(\mathrm{Zn})$, copper $(\mathrm{Cu})$, iron $(\mathrm{Fe})$, and manganese $(\mathrm{Mn})$. The analyses of micro-mineral content were conducted at the Agricultural Research and Extension Trust (ARET) Laboratories in Malawi. Five grams of defatted and dry samples, which were ashed at $550{ }^{\circ} \mathrm{C}$ for six hours, were solubilized in concentrated nitric acid. Then, five $\mathrm{ml}$ of 6 molar hydrochloric acid were added to the samples before they were assayed with a Varian atomic absorption spectrometer (Spectra AA20, Agilent Technologies, Australia). Any silica compounds that were present were removed by filtration. The filtrate was then diluted to the desired volume and aspirated into the air-acetylene flame of the atomic absorption spectrometer. The absorbance of each element was measured by comparison with the absorbance of calibration solutions for the same element. The adjusted wavelengths were copper $(\mathrm{Cu}): 324.8 \mathrm{~nm}$, iron $(\mathrm{Fe}): 248.3 \mathrm{~nm}$, manganese $(\mathrm{Mn}): 279.5 \mathrm{~nm}$, zinc $(\mathrm{Zn}): 213.8 \mathrm{~nm}$, and potassium (K): $766.5 \mathrm{~nm}$.

Data were analysed using the general linear model of IBM SPSS software version 22 (IBM Inc., Armonk, New York, USA). Multivariate analysis of variance was used to test the effects of production system, sex and the interactions among these factors. Differences between treatment means were tested using Duncan's multiple range test $(P<0.05)$. Each duck was regarded as an experimental unit and the statistical significance was set at $P$-value $<0.05$. Means and standard errors (SE) are reported.

\section{Results and Discussion}

There were no significant differences $(P>0.05)$ in the conversion of duck breast muscle to meat over the 24-hour post-mortem period, although numerically the carcass $\mathrm{pH}$ of ducks in IS decreased faster than those in other treatments (Figure 1), but retained similar values after 24 hours. The same trend was observed for carcass temperature (Figure 2). Pooled carcass temperature dropped from $27.45^{\circ} \mathrm{C}$ to $5.47^{\circ} \mathrm{C}$ and pooled carcass $\mathrm{pH}$ dropped from as high as 6.68 to 5.86, with the highest drop at six hours post mortem for both quality factors. Similarly, the study found no significant differences between production systems and sex for the initial ( 45 minutes) and final ( $24 \mathrm{hrs)} \mathrm{carcass} \mathrm{temperatures} \mathrm{and} \mathrm{pH}$ of Muscovy duck meat (Table 2). Generally, no interactions between production systems and sex were found, except on ultimate $\mathrm{pH}$. 


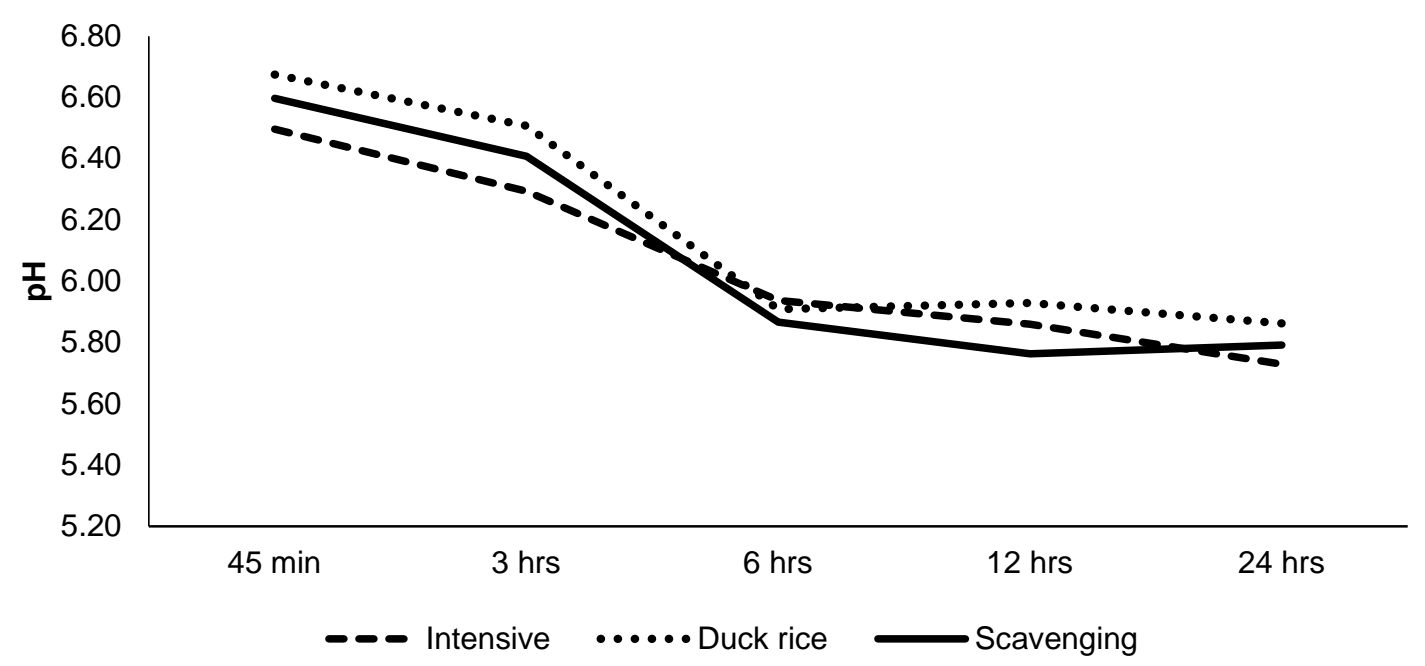

Figure 1 Carcass pH from 45 minutes to 24 hours post slaughter of ducks raised in different production systems

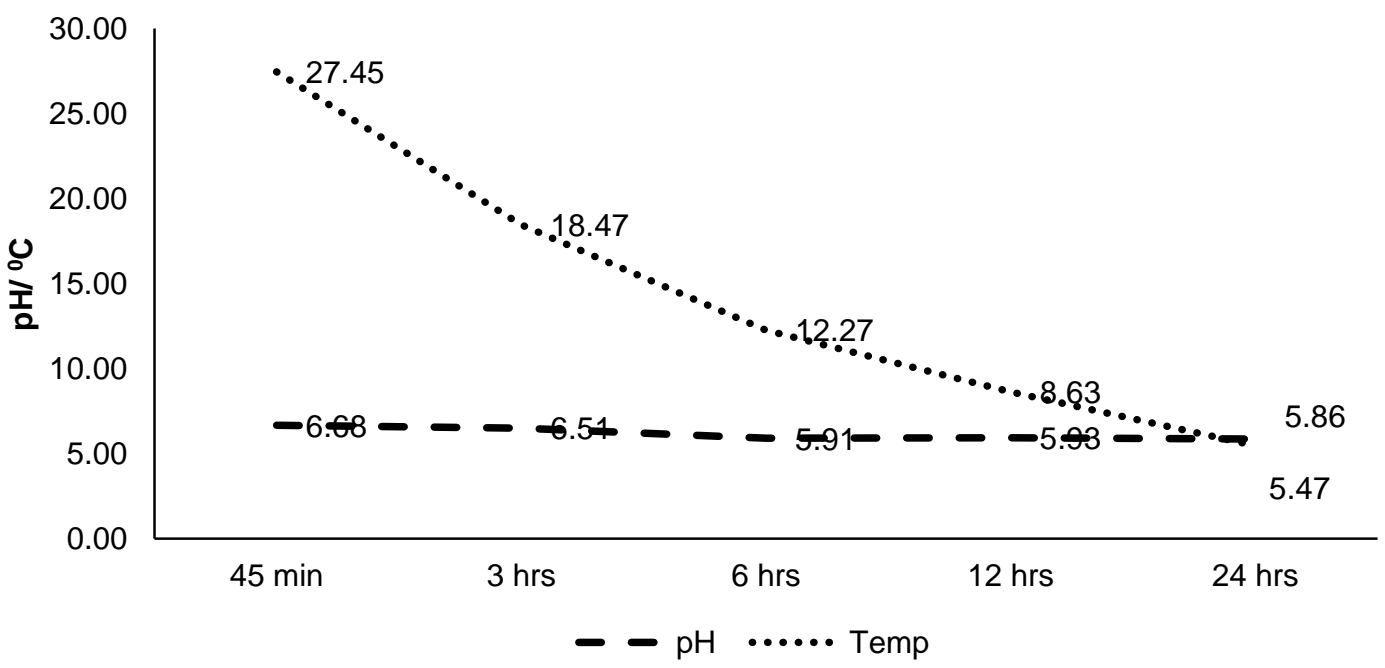

Figure 2 Carcass temperature and $\mathrm{pH}$ from 45 minutes to 24 hours post slaughter of ducks raised in different production systems 
Table 2 Means ( \pm SE) for carcass temperature and $\mathrm{pH}$ of breast meat of Muscovy ducks as affected by production system, sex and their interaction

\begin{tabular}{|c|c|c|c|c|c|c|c|}
\hline \multirow{2}{*}{ Sex } & \multicolumn{4}{|c|}{ Production system } & \multicolumn{3}{|c|}{ Level of significance $^{1}$} \\
\hline & Intensive & Duck-rice & Free range & Pooled & $\mathrm{P}$ & $\mathrm{s}$ & $P * S$ \\
\hline \multicolumn{8}{|c|}{ Initial pH (45 min) } \\
\hline Female & $6.42 \pm 0.14$ & $6.57 \pm 0.14$ & $6.80 \pm 0.14$ & $6.60 \pm 0.79$ & & & \\
\hline Male & $6.55 \pm 0.14$ & $6.60 \pm 0.14$ & $6.59 \pm 0.14$ & $6.58 \pm 0.79$ & & & \\
\hline Overall & $6.49 \pm 0.97$ & $6.59 \pm 0.97$ & $6.70 \pm 0.97$ & $6.59 \pm 0.56$ & 0.34 & 0.88 & 0.48 \\
\hline \multicolumn{8}{|c|}{ Ultimate $\mathrm{pH}(24 \mathrm{hr})$} \\
\hline Female & $5.80 \pm 0.65$ & $5.66 \pm 0.65$ & $5.78 \pm 0.65$ & $5.74 \pm 0.38$ & & & \\
\hline Male & $5.95 \pm 0.65$ & $5.93 \pm 0.65$ & $5.66 \pm 0.65$ & $5.84 \pm 0.38$ & & & \\
\hline Overall & $5.87 \pm 0.46$ & $5.79 \pm 0.46$ & $5.72 \pm 0.46$ & $5.79 \pm 0.27$ & 0.10 & 0.09 & 0.03 \\
\hline \multicolumn{8}{|c|}{ Initial temperature $\left({ }^{\circ} \mathrm{C}\right)(45 \mathrm{~min})$} \\
\hline Female & $27.10 \pm 0.62$ & $27.00 \pm 0.62$ & $27.70 \pm 0.62$ & $27.27 \pm 0.36$ & & & \\
\hline Male & $27.20 \pm 0.62$ & $26.90 \pm 0.62$ & $26.83 \pm 0.62$ & $26.98 \pm 0.36$ & & & \\
\hline Overall & $27.15 \pm 0.44$ & $26.95 \pm 0.44$ & $27.27 \pm 0.44$ & $27.12 \pm 0.25$ & 0.88 & 0.58 & 0.72 \\
\hline \multicolumn{8}{|c|}{ Final temperature $\left({ }^{\circ} \mathrm{C}\right)(24 \mathrm{hr})$} \\
\hline Female & $5.47 \pm 0.13$ & $5.60 \pm 0.13$ & $5.43 \pm 0.13$ & $5.50 \pm 0.08$ & & & \\
\hline Male & $5.50 \pm 0.13$ & $5.57 \pm 0.13$ & $5.40 \pm 0.13$ & $5.49 \pm 0.08$ & & & \\
\hline Overall & $5.43 \pm 0.94$ & $5.58 \pm 0.94$ & $5.42 \pm 0.94$ & $5.49 \pm 0.05$ & 0.48 & 0.92 & 0.96 \\
\hline
\end{tabular}

Muscle $\mathrm{pH}$ is important in the preservation and stability of meat, because high muscle $\mathrm{pH}$ results in shorter shelf life, especially as it pertains to microbial growth (Li et al., 2017). [not in refs] Muscle pH depends on the biochemical state of the muscle at the time of slaughter and the development of rigor mortis (Singh \& Pathak, 2017). Post-mortem muscle pH decline is important in terms of meat tenderness, colour, and waterholding capacity $\{\mathrm{WHC}$ ) (Aberle et al., 2001). which depends mainly on a decrease in $\mathrm{pH}$ and on protein degradation under the action of proteases (Baeza, 2006). It is a direct indication of meat quality in which glycogen reserves in muscles affect the post-mortem $\mathrm{pH}$ level. Duck muscle is regarded as red meat because it has $16 \%$ white fibres and $84 \%$ red fibres, compared with $100 \%$ white fibres in chicken breast (Smith et al., 1993), thus differences post mortem are expected (Ali et al., 2007). Generally, the mean ultimate $\mathrm{pH}$ value of duck meat is between 5.90 (Fernandez et al., 2003) and 5.65 (Raj et al., 1998). The current results are in agreement with those of Li et al. (2017), in which production system had no effect on $\mathrm{pH}$ level of breast meat and the lack of interaction between production systems and sex is similar to what Wang et al. (2009) and Fanatico et al. (2007) reported on ducks in a free-range system versus those in an intensive system. However, the values for ultimate $\mathrm{pH}$ in this study were higher than those reported by Erisir et al. (2009) and lower than reports by Ismed et al. (2009) and Khan et al. (2016). On the contrary, Raj et al. (1998), Mallia et al. (2000), Fernandez et al. (2003), and Lacin et al. (2008) reported that treatment had an effect on $\mathrm{pH}$ values, and found comparable ultimate $\mathrm{pH}$ values for ducks in IS environments, which were lower than FR and duck-fish rearing systems. The differences could be due to age of slaughter, which causes glycolytic metabolism in muscle to increase with age, inducing a decrease in ultimate $\mathrm{pH}$ value (Baéza et al., 1998) and glycogen levels during slaughter, which can be altered by many factors ante mortem and post mortem (Braden, 2013).

Lack of difference in pH between sexes in this study is similar to the findings of Liao et al. (2016) and Uhlírov et al. (2018) in Pekin ducks and Geldenhuys et al. (2015) in Egyptian geese. However, Kirmizibayrak et al. (2011) reported significantly higher ultimate $\mathrm{pH}$ of the breast muscles in females than in males. In the current results at 24 hours post mortem, the $\mathrm{pH}$ values on breast meat between sex showed female ducks were slightly lower (5.74) than males (5.84). It is reported that lower pH (5.7) at 24 hours post mortem indicates poor meat quality (Van Laack et al., 2000). All the production systems presented overall pH24 values between 5.72 and 5.87, an indication of good meat quality. The higher ultimate pH above 5.7 at 24 hours in this study could be due to the fasting period and exposure to high temperatures before slaughter 
(Baéza, 1995). However, the pooled ultimate $\mathrm{pH}$ in this study was lower than that reported by Liao et al. (2016). Differences in $\mathrm{pH}$ values could be attributed to differences in the glycogen reserves at slaughter, responses to pre-slaughter stress and slaughter weight (Uhlírov et al., 2018).

The colour of the pectoralis muscle was affected by production system only in terms of lightness $\left(L^{*}\right)$ at $45 \mathrm{~min}$, and by the sex of the duck on redness $\left(a^{*}\right)$ at 24 hours $(P<0.5)$. Interactions between production systems and sex were observed on lightness $\left(L^{*}\right)$ and yellowness $\left(b^{*}\right)$ at $45 \min$ (Table 3 ). Generally, the colour of pectoralis muscle at 24 hours post mortem was not affected by production systems.

Table 3 Means ( \pm SE) for the colour of duck breast meat as affected by production system, sex and their interaction

\begin{tabular}{|c|c|c|c|c|c|c|c|c|}
\hline \multirow{2}{*}{ Time } & \multirow{2}{*}{ Sex } & \multicolumn{3}{|c|}{ Production system } & \multirow[b]{2}{*}{ Pooled } & \multicolumn{3}{|c|}{ Level of significance $^{1}$} \\
\hline & & Intensive & Duck rice & Free range & & $\mathrm{P}$ & $\mathrm{S}$ & $P * S$ \\
\hline \multicolumn{9}{|c|}{ Lightness $\left(L^{*}\right)$} \\
\hline \multirow[t]{3}{*}{$45 \min$} & Female & $65.4 \pm 2.12$ & $52.3 \pm 2.12$ & $61.3 \pm 2.12$ & $59.8 \pm 1.22$ & & & \\
\hline & Male & $61.3 \pm 2.12$ & $57.0 \pm 2.12$ & $52.4 \pm 2.12$ & $58.8 \pm 1.22$ & & & \\
\hline & Overall & $63.3^{\mathrm{a}} \pm 1.49$ & $57.8^{\mathrm{b}} \pm 1.49$ & $56.8^{\mathrm{b}} \pm 1.49$ & $59.3 \pm 0.86$ & 0.02 & 0.55 & 0.01 \\
\hline \multirow[t]{3}{*}{$24 \mathrm{hr}$} & Female & $32.3 \pm 4.34$ & $31.2 \pm 4.34$ & $38.2 \pm 4.34$ & $34.1 \pm 2.53$ & & & \\
\hline & Male & $43.7 \pm 4.34$ & $34.1 \pm 4.34$ & $45.9 \pm 4.34$ & $41.2 \pm 2.53$ & & & \\
\hline & Overall & $38.3 \pm 3.10$ & $32.7 \pm 3.10$ & $42.1 \pm 3.10$ & $37.7 \pm 1.79$ & 0.14 & 0.07 & 0.67 \\
\hline \multicolumn{9}{|c|}{ Redness $\left(a^{\star}\right)$} \\
\hline \multirow[t]{3}{*}{$45 \mathrm{~min}$} & Female & $4.83 \pm 1.42$ & $9.65 \pm 1.42$ & $6.61 \pm 1.42$ & $7.03 \pm 0.82$ & & & \\
\hline & Male & $8.00 \pm 1.42$ & $5.26 \pm 1.42$ & $11.4 \pm 1.42$ & $8.22 \pm 0.82$ & & & \\
\hline & Overall & $6.42 \pm 1.00$ & $7.46 \pm 1.00$ & $9.00 \pm 1.00$ & $7.63 \pm 0.58$ & 0.23 & 0.33 & 0.16 \\
\hline \multirow[t]{3}{*}{$24 \mathrm{hr}$} & Female & $12.4^{x} \pm 1.35$ & $10.5^{x} \pm 1.35$ & $14.9^{x} \pm 1.35$ & $12.6^{x} \pm 0.78$ & & & \\
\hline & Male & $9.12^{y} \pm 1.35$ & $11.0^{y} \pm 1.35$ & $9.77^{y} \pm 1.35$ & $9.99^{y} \pm 0.78$ & & & \\
\hline & Overall & $10.8 \pm 0.95$ & $10.8 \pm 0.95$ & $12.3 \pm 0.95$ & $11.3 \pm 0.55$ & 0.43 & 0.04 & 0.15 \\
\hline \multicolumn{9}{|c|}{ Yellowness $\left(b^{\star}\right)$} \\
\hline \multirow[t]{3}{*}{$45 \mathrm{~min}$} & Female & $13.3 \pm 1.26$ & $10.2 \pm 1.26$ & $14.7 \pm 1.26$ & $12.7 \pm 0.73$ & & & \\
\hline & Male & $14.5 \pm 1.26$ & $13.1 \pm 1.26$ & $10.1 \pm 1.26$ & $12.5 \pm 0.73$ & & & \\
\hline & Overall & $13.9 \pm 0.89$ & $11.6 \pm 0.89$ & $12.4 \pm 0.89$ & $12.6 \pm 0.51$ & 0.23 & 0.85 & 0.03 \\
\hline \multirow[t]{3}{*}{$24 \mathrm{hr}$} & Female & $12.8 \pm 1.50$ & $9.76 \pm 1.50$ & $14.2 \pm 1.50$ & $12.2 \pm 0.87$ & & & \\
\hline & Male & $12.4 \pm 1.50$ & $9.48 \pm 1.50$ & $12.6 \pm 1.50$ & $11.5 \pm 0.87$ & & & \\
\hline & Overall & $12.6 \pm 1.06$ & $9.62 \pm 1.06$ & $13.4 \pm 1.06$ & $11.9 \pm 0.61$ & 0.06 & 0.56 & 0.90 \\
\hline
\end{tabular}

Meat colour is the most important sensory attribute that affects consumer purchasing decisions, and is affected predominantly by myoglobin, which is the primary red pigment in meat (del Puerto et al., 2016) and influences consumer preferences (Pripwai et al., 2014; Pathare \& Roskilly, 2016), since it indicates meat freshness and the level of doneness (Chang et al., 2011). Fibre type and myoglobin content have a strong effect on meat colour. Like other eating quality attributes, meat colour is affected by factors such as species, animal genetics, rearing systems, post-mortem changes in muscle (especially the dynamics of $\mathrm{pH}$ and carcass temperature decline). Poultry meat colour is also affected by sex, age, processing method, exposure to chemicals; cooking method, irradiation and freezing (Huda et al. 2009). Among the various studies on colour values of the raw pectoralis muscle of ducks, the current results on overall lightness $(L * 37.7)$ at 24 hours post mortem are consistent with those of Smith et al. (1993) (36.45), Raj et al. (1998) (38), Baeza et al. (2002) (39.6), and Fernandez et al. (2003) (40.5). The current results on overall redness at 24 hours post mortem $\left(a^{\star}=11.3\right)$ and yellowness $\left(b^{\star}=11.9\right)$ are closer to what was reported by Baeza et al. $(2002)$, who 
found $a^{*}=13.86$ and $b^{*}=12.18$. However, ducks from FR and DR integration had brighter pectoralis muscle than those from IS. This finding is supported by Ponte et al. (2008), who reported that birds from a freerange system were characterized by a brighter colour of meat and a higher contribution of yellow colour in muscles, owing to their diet, which included green forage rich in natural carotenoids. These green forages cause the deposition of melanin and xanthophyll into the skin and give its colour. Ducks on free range and duck-rice integration were more active than those in the intensive system, thus they used more oxygen in their muscles, which requires more myoglobin and a greater supply of oxygen from blood to the muscle cells. Because the iron content of duck meat is high, the meat from free range and duck-rice integration appeared darker than those from the intensive system. In the previous discussion, it was observed that duck meat $\mathrm{pH}$ from duck-rice and free range had slightly higher $\mathrm{pH}$ and some studies reported a high correlation between ultimate muscle $\mathrm{pH}$ and meat colour, especially lightness. Fletcher et al. (2000) reported that muscles with a high $\mathrm{pH}$ have a darker colour than those with a low $\mathrm{pH}$. In the current study, meat from duck-rice and freerange systems, which had numerically higher $\mathrm{pH}$ values, was darker than that from the intensive system. Hence, rearing systems affect the physical parameters of muscles and may significantly affect consumers' choice and preferences (Fanatico et al., 2007). On the other hand, sex had a significant effect on lightness and redness and females had higher values of redness $\left(a^{*}\right)$ than males $(P<0.05)$. No differences between females and males were observed for lightness and yellowness $(P>0.05)$. The results in muscle redness and yellowness at 24 hours from this study between the sexes agree with those of Uhliřov et al. (2018) in geese.

The effects of production system and sex of ducks on tenderness and cooking losses of duck meat are presented in Table 4. The results confirmed that the tenderness of duck breast meat was affected by both production system and sex $(P<0.05)$, while cooking loss was not influenced by either of these factors. As indicated by shear force, ducks kept in IS had more tender breast meat $(1.56 \mathrm{~kg})$, followed by ducks in DR integration $(1.95 \mathrm{~kg})$, and the least tender meat was from ducks in the FR system $(2.28 \mathrm{~kg})$. However, further comparisons showed that tenderness of duck breast for ducks in DR was not different from that of ducks in the FR system. In addition, there was an interaction between production system and sex on tenderness of duck breast meat $(P=0.009)$

Table 4 Means $( \pm$ SE) for the influence of production system, sex and their interactions on tenderness and cooking loss of breast meat of Muscovy ducks

\begin{tabular}{|c|c|c|c|c|c|c|c|}
\hline \multirow[b]{2}{*}{ Sex } & \multicolumn{4}{|c|}{ Production system } & \multicolumn{3}{|c|}{ Level of significance $^{1}$} \\
\hline & Intensive & Duck rice & Free range & Pooled & $\mathrm{P}$ & $\mathrm{S}$ & $\mathrm{P} * \mathrm{~S}$ \\
\hline \multicolumn{8}{|c|}{ Tenderness (kg force) } \\
\hline Female & $1.47^{x} \pm 0.23$ & $1.67^{x} \pm 0.23$ & $1.40^{x} \pm 0.23$ & $1.51^{x} \pm 0.13$ & & & \\
\hline Male & $1.33^{y} \pm 0.23$ & $2.23^{y} \pm 0.23$ & $3.17^{y} \pm 0.23$ & $2.24^{y} \pm 0.13$ & & & \\
\hline Overall & $1.87^{\mathrm{a}} \pm 0.16$ & $1.95^{b} \pm 0.16$ & $2.28^{b} \pm 0.16$ & $1.88 \pm 0.09$ & 0.01 & 0.01 & 0.01 \\
\hline \multicolumn{8}{|c|}{ Cooking loss (\%) } \\
\hline Female & $31.7 \pm 2.64$ & $31.7 \pm 2.64$ & $26.7 \pm 2.64$ & $30.6 \pm 1.52$ & & & \\
\hline Male & $28.3 \pm 2.64$ & $33.3 \pm 2.64$ & $31.7 \pm 2.64$ & $30.6 \pm 1.52$ & & & \\
\hline Overall & $30.0 \pm 0.16$ & $32.5 \pm 0.16$ & $29.2 \pm 0.16$ & $30.6 \pm 1.08$ & 0.44 & 1.00 & 0.86 \\
\hline
\end{tabular}

Meat palatability is the primary sensory trait of consumer acceptance (Choi et al., 2016), and the main attribute of palatability that influences consumer acceptance is tenderness (Mennecke et al., 2007; Piao et al., 2015), especially for consumer decisions on repeat purchases (Grunert et al., 2004). It is dictated by the presence of several factors, including the amount of fat, water-holding capacity (WHC) and the actomyosin complex (Singh \& Pathak, 2017) and processing techniques (Adam \& Abugroun, 2015). The results from the current study on the effect of production systems on tenderness are in line with those of Michalczuk et al. (2014), who reported that meat from chickens on a FR system was characterised by higher shear force, and therefore was tougher than the meat of chickens from IS. In their studies Chen et al. (2006) and Farmer et al. (1997) reported significant production system effects, with higher shear force values of drumstick and 
breast meat of chickens raised organically, which is similar to the FR system in the current study. However, it was not surprising to have duck meat from IS that was more tender than meat from DR and FR systems, since ducks under IS had restricted space allowances in the house, so the muscles were not under heavy exercise as a result of walking longer distances (Mutibvu et al., 2017). However, shear force values in this study were lower than those that Ali et al. (2007) reported for Chungdong ori ducks. Numerically, meat from ducks in DR was more tender than that from the FR system, because ducks in the DR had some restricted movement in the rice field, which was fenced, as opposed to ducks in FR, where there was no limitation of movement, resulting in greater muscle activity. The effects of production systems on carcass and meat quality, and in particular meat tenderness have been confirmed in other livestock (Webb \& Erasmus, 2013). The results of the effect of sex on meat tenderness in this study are in line with those of Chen et al. (2006), who found higher shear force values in males than females in two chicken breeds (Anka and Rugao). However, the results are contrary to the findings by Smith et al. (2015), who did not find differences in tenderness between male and female Pekin ducks, and to those of Uhlírov et al. (2018) in geese and to Huff-Lonergan et al. (1995) in the bovine longissimus muscle. The use of Muscovy ducks in the present study may explain the difference between sexes.

Cooking loss is a critical factor in the meat industry because it determines the technological yield of the cooking process (Kondjoyan, 2013) and serves as an indicator of WHC, which affects meat quality. From a nutritional point of view, cooking loss brings about loss of soluble proteins, vitamins and different supplements (Yarmand et al., 2013) and depends on cooking time and cooking temperatures (Adam \& Abugroun, 2015). In this study, cooking loss was not affected by production system or sex, which agrees with the findings of other studies (Lopez et al., 2011; Uhlírov et al., 2018). The values in the present study were lower than those reported by Alvarado and Sams (2000) and Ali et al. (2007). However, Musundire et al. (2017) reported that cooking loss was affected $(P<0.05)$ by sex in chickens and guinea fowl managed under village FR systems. The differences are due to species, age at slaughter, and conditions in the management system.

The nutritional composition of breast muscle from Muscovy ducks is presented in Table 5 and shows that production system had no effect on any of the nutrients that were analysed. However, sex had an effect $(P<0.05)$ on moisture, with males containing a higher percentage of moisture than females. The proximate composition in breast was not affected by interaction between production system and sex.

Table 5 Means ( \pm SE) for proximate composition of breast meat of Muscovy ducks as affected by production system, sex and their interaction

\begin{tabular}{|c|c|c|c|c|c|c|c|}
\hline \multirow{2}{*}{ Sex } & \multicolumn{3}{|c|}{ Production system } & \multicolumn{4}{|c|}{ Level of significance $^{1}$} \\
\hline & Intensive & Duck rice & Free range & Pooled & $\mathrm{P}$ & $\mathrm{S}$ & $\mathrm{P} * \mathrm{~S}$ \\
\hline \multicolumn{8}{|c|}{ Moisture (\%) } \\
\hline Female & $62.2 \pm 1.92$ & $61.7 \pm 1.92$ & $61.2 \pm 1.92$ & $61.7 \pm 1.11$ & & & \\
\hline Male & $66.2 \pm 1.92$ & $64.8 \pm 1.92$ & $65.7 \pm 1.92$ & $65.6 \pm 1.11$ & & & \\
\hline Overall & $64.2 \pm 1.35$ & $63.2 \pm 1.35$ & $63.4 \pm 1.35$ & $63.6 \pm 0.78$ & 0.63 & 0.03 & 0.94 \\
\hline \multicolumn{8}{|l|}{ Protein (\%) } \\
\hline Female & $20.3 \pm 1.22$ & $20.9 \pm 1.22$ & $21.4 \pm 1.22$ & $21.1 \pm 0.70$ & & & \\
\hline Male & $21.8 \pm 1.22$ & $22.7 \pm 1.22$ & $23.3 \pm 1.22$ & $22.0 \pm 0.70$ & & & \\
\hline Overall & $21.2 \pm 0.86$ & $21.8 \pm 0.86$ & $21.8 \pm 0.86$ & $21.6 \pm 0.50$ & 0.55 & 0.39 & 0.18 \\
\hline \multicolumn{8}{|l|}{ Fat (\%) } \\
\hline Female & $3.55 \pm 1.02$ & $6.22 \pm 1.02$ & $5.91 \pm 1.02$ & $5.23 \pm 0.59$ & & & \\
\hline Male & $4.82 \pm 1.02$ & $4.53 \pm 1.02$ & $3.65 \pm 1.02$ & $4.33 \pm 0.59$ & & & \\
\hline Overall & $4.18 \pm 0.72$ & $5.37 \pm 0.72$ & $4.78 \pm 0.72$ & $4.78 \pm 0.42$ & 0.29 & 0.30 & 0.22 \\
\hline \multicolumn{8}{|l|}{ Ash (\%) } \\
\hline Female & $6.21 \pm 1.33$ & $6.79 \pm 1.33$ & $5.75 \pm 1.33$ & $6.25 \pm 0.77$ & & & \\
\hline Male & $6.80 \pm 1.33$ & $6.32 \pm 1.33$ & $6.38 \pm 1.33$ & $6.50 \pm 0.77$ & & & \\
\hline Overall & $6.50 \pm 0.94$ & $6.56 \pm 0.94$ & $6.07 \pm 0.94$ & $6.38 \pm 0.54$ & 0.73 & 0.82 & 0.90 \\
\hline
\end{tabular}


The nutritional composition of duck meat varies, depending on the breed and strain of duck and diet (Ramadhan et al., 2010). The present results agree with those of Holcman et al. (2003) and Michalczuk et al. (2014), who found no significant differences in the chemical composition of muscle due to rearing system. In their studies, Holcman et al. (2003) and Lorenzo et al. (2011) reported that sex did not influence the proximate analysis of breast meat, which may indicate similar skeletal muscle composition between sexes, though not in moisture for this study, which was influenced by sex.

The overall moisture content of duck meat in the current study was lower than that reported by Chartin et al. (2006), Ali et al. (2007), Lorenzo et al. (2011), Galal et al. (2011) and Ismed et al. (2013) in Muscovy ducks, and Baeza et al. (2000) in mule ducks. These differences could be due to age at slaughter, which affects the proximate composition and especially moisture content (Wattanachant, 2008) as it decreases with age. The effect of sex on moisture, whereby males had significantly higher values than females in this study, is comparable with findings by Baeza et al. (2000) and Zangh et al. (2010).

Levels of protein found here in duck meat are in line with studies by Ali et al. (2007), who found $20.1 \%$ crude protein (CP), Ensminger et al. (1993), who found 21.4\% CP, Rahman (2014), who found 20.3\% CP, and Cobos et al. (2000), who found 20.08\% CP. However, the current results are lower than values reported by Lorenzo et al. (2011), who recorded a protein level of $24.29 \%$ CP. On the other hand, the current protein value is higher than the $18.3 \%$ reported by the USDA (2015), and the $17.9 \%$ reported by Ismed et al. (2013). These differences could be as a result of age at slaughter, breed and management system, since the other authors did not specify the breeds of duck. Age at slaughter also affects the protein content of meat, whereby an increase in age results in a decrease in protein content.

The fat content of meat is affected by breed, feeding and age at slaughter. In free-ranging Guinea fowls and chickens fat has been observed to increase with age and females have more fat than males (Musundire et al., 2017). The pooled fat composition found in this study, ranging from 4.18 to $5.37 \%$, is in agreement with results of Chartin et al. (2006), Ismed et al. (2013) and USDA (2015), but higher than the results of Mazanowski et al. (2003), who reported fat content of $1.7 \%$ in specialized sire lines. Though not statistically different numerically, it was observed that ducks kept in free range and duck-rice integration were slightly fatter that those in intensive systems. This may be due to the wide range of feedstuffs that are available to the ducks in the vicinity. Feedstuffs such as grass, insects, frogs and small animals that are eaten by the scavenging ducks could have contributed to their high fat and ash contents, since grass is digested by the ducks in the colon and thereby supplies energy, which is usually stored as fat (Tougan et al., 2003). However, the tendency for birds to deposit fat is genetically driven, indicating that fatness and leanness have to be modified at breeding level for sustainable improvement (Grashorn, 2010). On the other hand, the relationship between fat and moisture in this study, whereby the pooled moisture content for males was slightly higher than for females and affected the fat content negatively, agrees with works of Stankov et al (2002), Chowdhury and Mutalib (2003) and Rahman (2012), who reported that the decrease in moisture content in meat is due to the increase in fat content.

While the ash content of duck breast meat in this study was higher than values reported by Zhou et al. (2000) and Baeza et al. (2002), the current results on ash content are in line with those of Ali et al. (2007), Ismed et al. (2013) and USDA (2015). The significantly high ash of the ducks on free range might be attributed to the season of production. The study was conducted at the start of the rainy season in Malawi, when the grasses were young and more nutritious, and had a relatively high mineral value. These grasses are liked by scavenging birds, and contribute to the high mineral level. The season is also characterized by snails, worms, and small insects, which contain high levels of minerals, and might have contributed to this high ash content (Tougan et al., 2003).

The minerals of the duck breast muscle were affected by the production system $(P<0.05)$ except for potassium. No effects of sex or interactions between sex and production systems were observed on the minerals of duck breast muscle (Table 6). The general trend in this study was that free-range ducks had the highest values of all minerals, followed by those in duck-rice integration, and the intensively managed ducks had the lowest minerals. However, differences between production systems were observed for manganese, zinc and copper $(P<0.05)$.

Minerals are present in the animal body in concentrations not greater than $50 \mathrm{mg} / \mathrm{kg}(0.05 \mathrm{mg} / \mathrm{g})$ (McDonald et al., 2010). Ash is an indication of the total amount of minerals in the muscle and the quantity can vary as a result of species differences, hormones, age, sex, region and diet (Keeton \& Eddy, 2004). An increase in mineral levels in the current study was as a result of higher ash values (Table 5), which agrees with what Musundire at al. (2017) reported. The high mineral levels of the ducks in the FR and DR systems than ducks in the intensive system are explained by the high values of ash in Table 5, which are attributed to availability of feed resources for scavenging birds, which influence their ash content (Tougan et al., 2013), and consequently the high micro-minerals. 
Table 6 Means $( \pm$ SE) for production system, sex and their interaction effects on the mineral composition of breast meat from Muscovy ducks

\begin{tabular}{|c|c|c|c|c|c|c|c|}
\hline \multirow{2}{*}{ Sex } & \multicolumn{4}{|c|}{ Production system } & \multicolumn{3}{|c|}{ Level of significance $^{1}$} \\
\hline & Intensive & Duck-rice & Free-range & Overall & $\mathrm{P}$ & $\mathrm{S}$ & $P * S$ \\
\hline \multicolumn{8}{|c|}{ Zinc mg/100 g } \\
\hline Female & $0.99 \pm 1.52$ & $1.28 \pm 1.52$ & $1.37 \pm 1.52$ & $1.21 \pm 0.09$ & & & \\
\hline Male & $0.95 \pm 1.52$ & $1.32 \pm 1.52$ & $1.43 \pm 1.52$ & $1.24 \pm 0.09$ & & & \\
\hline Overall & $0.97^{\mathrm{a}} \pm 0.11$ & $1.30^{\mathrm{ab}} \pm 0.11$ & $1.40^{\mathrm{b}} \pm 0.11$ & $1.23 \pm 0.06$ & 0.04 & 0.85 & 0.93 \\
\hline \multicolumn{8}{|c|}{ Iron mg/100 g } \\
\hline Female & $1.05 \pm 0.71$ & $2.19 \pm 0.71$ & $2.91 \pm 0.71$ & $2.50 \pm 0.41$ & & & \\
\hline Male & $1.42 \pm 0.71$ & $3.65 \pm 0.71$ & $2.85 \pm 0.71$ & $2.64 \pm 0.41$ & & & \\
\hline Overall & $1.24^{\mathrm{a}} \pm 0.50$ & $2.92^{b} \pm 0.50$ & $2.88^{b} \pm 0.50$ & $2.35 \pm 0.29$ & 0.06 & 0.33 & 0.56 \\
\hline \multicolumn{8}{|c|}{ Copper mg/100 g } \\
\hline Female & $0.18 \pm 0.08$ & $0.34 \pm 0.08$ & $0.42 \pm 0.08$ & $0.32 \pm 0.05$ & & & \\
\hline Male & $0.19 \pm 0.08$ & $0.46 \pm 0.08$ & $0.48 \pm 0.08$ & $0.38 \pm 0.05$ & & & \\
\hline Overall & $0.19^{a} \pm 0.06$ & $0.40^{b} \pm 0.06$ & $0.45^{\mathrm{b}} \pm 0.06$ & $0.35 \pm 0.32$ & 0.01 & 0.35 & 0.77 \\
\hline \multicolumn{8}{|c|}{ Manganese $\mathrm{mg} / 100 \mathrm{~g}$} \\
\hline Female & $0.09 \pm 0.08$ & $0.36 \pm 0.08$ & $0.28 \pm 0.08$ & $0.24 \pm 0.04$ & & & \\
\hline Male & $0.23 \pm 0.08$ & $0.43 \pm 0.08$ & $0.33 \pm 0.08$ & $0.33 \pm 0.04$ & & & \\
\hline Overall & $0.16^{a} \pm 0.05$ & $0.40^{b} \pm 0.05$ & $0.31^{\mathrm{ab}} \pm 0.05$ & $0.29 \pm 0.03$ & 0.03 & 0.18 & 0.90 \\
\hline \multicolumn{8}{|c|}{ Potassium mg/100 g } \\
\hline Female & $91.6 \pm 11.1$ & $88.0 \pm 11.1$ & $98.5 \pm 11.1$ & $92.7 \pm 6.41$ & & & \\
\hline Male & $62.4 \pm 11.1$ & $101 \pm 11.1$ & $92.6 \pm 11.1$ & $85.4 \pm 6.41$ & & & \\
\hline Overall & $77.0 \pm 7.86$ & $94.6 \pm 7.86$ & $95.5 \pm 7.86$ & $89.0 \pm 4.54$ & 0.21 & 0.43 & 0.20 \\
\hline
\end{tabular}

\section{Conclusion}

The duck-rice integrated system is a new farming system in Malawi, but has proved to be a useful alternative alongside free-range and intensive systems. The results from this study indicate that the use of duck-rice integration improves the nutritive value of duck meat to levels that comparable with free-range systems because of the freedom of birds to scavenge. The use of the duck-rice integration system produced more tender breast meat than from free-range systems, but less so than from intensive systems. The study also concurred with other studies on the effect of sex on meat tenderness, whereby females produced more tender duck breast meat than males. On the other hand, production systems had no effect on the proximate composition of Muscovy duck breast meat, while sex affected only the moisture content, with males containing more moisture than females. Therefore, farmers could adopt the duck-rice integrated system as an alternative to the current free-range system with supplementation to improve the nutritional value and meat quality of native Malawian Muscovy ducks. However, further on-farm studies need to be conducted before implementation on a full scale, since this was an on-station study with most of the factors under control.

\section{Acknowledgement}

The authors gratefully acknowledge the Department of Agricultural Research and Services (DARS) in Malawi for financial and material support for the completion of this study through the Agricultural Productivity Programme for Southern Africa (APPSA), members of staff and management at the University of Pretoria in the Republic of South Africa and Lilongwe University of Agriculture and Natural Resources in Malawi for their support, the director and management of Kanengo abattoir in Malawi for allowing the ducks to be slaughtered at their facility and M. Jose, F. Mbano, S. R. Mussah, P. Chisembe, M. Kaligambe, M. Mbalani, L. C. Chatepa and C. Mindozo for their support in lab analysis. 


\section{Authors' Contributions}

This work was part of the PhD in Animal Science study at the University of Pretoria. JT was the student and in charge of the experimental design, preparation and execution of the project in Malawi. ECW was the supervisor for the $\mathrm{PhD}$ research and participated in project planning and implementation and in results, statistics and interpretation of the study. JT as a student wrote the manuscript. ECW edited and corrected the manuscript for submission.

\section{Conflict of Interest Declaration}

There is no conflict of interest.

\section{References}

Aberle, E.D., Forrest, J.C., Gerrard, D.E., Mills, E.W., Hedrick, H.B., Judge, M.D., Merkel, R.A. \& Aberle, E.D., 2001. Principles of meat science. Kendall Hunt, Dubuque, lowa, USA.

Adam, Y.S.I. \& Abugroun, H.A., 2015. Evaluation of traditional cooking methods on eating meat characteristics and chemical composition. J. Agric. Vet. Sci. 8(4), 2319-2372, DOI: 10.9790/2380-08421217

Ali, S., Kang, G.H., Yang, H.S., Jeong, J.Y., Hwang, Y.H., Park, G.B. \& Joo, S.T., 2007. A comparison of meat characteristics between duck and chicken breast. Asian-Austra. J. Anim. Sci. 20, 1002-1006. DOI: https://doi.org/10.5713/ajas.2007.1002

Alvarado, C.Z. \& Sams, A.R., 2000. The influence of postmortem electrical stimulation on rigor mortis development, calpastatin activity, and tenderness in broiler and duck pectoralis. Poult. Sci. 79(9), 1364-1368. https://www.ncbi.nlm.nih.gov/pubmed/11020086

Ankom Methods, 2001. Method for crude fat determination. Ankom Technology Corporation, Macedon, NY.

AOAC International, 2005. Official methods of analysis of AOAC International. AOAC International. 18th edition, Association of Official Analytical Chemists, Washington DC, USA.

Baeza, E., 1995. La viande de canard: production et principales caractéristiques. INRA Productions Animales 8, 117125.

Baeza, E., 2006. Major trends in research into domestic ducks and recent results concerning meat quality. In: Proc. 12th European Poult. Conf., 10-24September, 2006, Verona, Italy. http://prodinra.inra.fr/record/17476

Baeza, E., Salichon, M.R., Marche, G. \& Juin, H., 1998. Effect of sex on growth, technological and organoleptic characteristics of the Muscovy duck breast muscle. Br. Poult. Sci. 39, 398-403.

Baeza, E., Dessay, C., Wacrenier, N., Marche, G. \& Listrat, A., 2002. Effect of selection for improved body weight and composition on muscle and meat characteristics in Muscovy duck. Br. Poult. Sci. 43, 560-568.

Baeza, E., Salichon, M.R., Marche, G., Wacrenier, N., Dominguez, B. \& Culioli, J., 2000. Effects of age and sex on the structural, chemical and technological characteristics of mule duck meat. Br. Poult. Sci. 41, $300-307$. DOI: $10.1080 / 713654934$

Braden, K.W., 2013. Converting muscle to meat: The physiology of rigor. In: The science of meat quality, edited by C.R. Kerth. John Wiley \& Sons, Oxford, UK. DOI: 10.1002/9781118530726.ch5

Chang, H.J., Xu, X.L., Li, C.B., Huang, M., Liu, J.D.Y. \& Zhou, G.H., 2011. A comparison of heat-induced changes of intramuscular connective tissue and collagen of beef semitendinosus muscle during water bath and microwave heating. J. Food Process. Eng. 34(6), 2233-2250.

Chartrin P., Méteau, K., Juin, H., Bernadet, M.D., Guy, G., ..., Baéza, E., 2006. Effects of intramuscular fat levels on sensory characteristics of duck breast meat. Poult. Sci. 85, 914-922

Chen, G.H., Cheng, J.H., Shuiep, Eltahir, Bao, W.B. \& Musa, H., 2006. Breed and sex effect on meat quality of chicken. Intern. J. Poult. Sci. 5. DOI: 10.3923/ijps.2006.566.568

Choi, J.H., Choi, Y.S., Kim, H.W., Song, D.H. \& Kim, C.J., 2016. Effects of post-mortem temperature on the physiochemical characteristics of prerigor Pekin duck breast muscles. Poult. Sci. 95, 645-650. DOI: $10.3382 /$ ps/pev263

Chowdhury, S.A. \& Mutalib, A., 2003. Goat production in Bangladesh present status and future programme. In: M. Afzal \& R.H. Usmani (eds). Goat production in SAARC countries, Pakistan Agricultural Research Council, Islamabad, Pakistan. Pp. 6-28.

Cobos, A., Veiga, A. \& Diaz, O., 2000. Chemical and fatty acid composition of meat and liver of wild ducks (Anas platyhynchos). Food Chem. 68, 77-79.

Department of Animal Health and Livestock Development, 2017. Ministry of Agriculture, Irrigation and Water Development, Lilongwe, Malawi.

del Puerto, M., Terevinto, A., Saadoun, A., Olivero, R. \& Cabrera, M.C., 2016. Effect of different sources of dietary starch on meat quality, oxidative status and glycogen and lactate kinetic in chicken pectoralis muscle. J. Food Nutr. Res. 4 (3), 185-194. DOI: 10.12691/jfnr-4-3-9

Ensminger, A.H., Ensminger, M.E., Konlande, J.E. \& Robson, J.R., 1993. Encyclopedia of food science, food technology and nutrition. 2nd ed. Academic Press, Orlando, Fla. Pp. 920-931

Erisir, Z., Poyraz, O., Onbasilar, E.E. Erdem, E. \& Oksuztepe, G.A., 2009. Effects of housing system, swimming pool and slaughter age on duck performance, carcass and meat characteristics. J. Anim. Vet. Advan. 8, 1864-1869

Fanatico, A.C., Pillai, P.B., Emmert, J.L. \& Owens, C.M., 2007. Meat quality of slow- and fast-growing chicken genotypes fed low-nutrient or standard diets and raised indoors or with outdoor access. Poult Sci. 86, 2245-2255.

Farmer, L.J., Perry, G.C., Lewis, P.D., Nute, G.R., Piggott, J.R. \& Patterson, R.L.S., 1997. Responses of two genotypes of chicken to the diets and stocking densities of conventional UK and label rouge production system. II. Sensory attributes. Meat Sci. 47, 77-93 
FAO 2008. Animal Production and Health Division, Emergency Centre for Transboundary Animal Diseases. Socio Economics, Production and Biodiversity Unit: Poultry Sector Country Review: An Analysis of the Poultry Sector in Ethiopia. FAO, Rome, Italy.

FAO 2013. Current Worldwide Annual Meat Consumption per capita, Livestock and Fish Primary Equivalent, FAO, Rome, Italy. http://faostat.fao.org/site/610/DesktopDefault.aspx?PagelD=610\#ancor

FAO 2016. Livestock-related interventions during emergencies - The how-to-do-it manual. Edited by P. Ankers, S. Bishop, S. Mack \& K. Dietze. FAO Animal Production and Health Manual No. 18. FAO, Rome.

FAO (Food and Agriculture Organization of the United Nations. 2017). Animal health and production. FAO, Rome

Fernandez, X., Auvergne, A., Renerre, M., Gatellier, P., Manse, H. \& Babile, R., 2003. Preliminary observations on the colour variability of breast meat ('magrets') in force-fed ducks. Anim. Res. 52, 567-574.

Fletcher, D.L., Qiao, M. \& Smith, D.P., 2000. The relationship of raw broiler breast meat colour and pH to cooked meat colour and $\mathrm{pH}$. Poult. Sci. 79, 784-788.

Galal, A., Ali, W.A., Ahmed, A.M. \& Ali, K.A. 2011. Performance and carcass characteristics of Dumyati, Muscovy, Peking and Sudani duck breeds. Egypt. J. Anim. Prod. 48, 191-202.

Gondwe, T.N.P., 2004. Characterisation of local chicken in low input-low output production systems: Is there scope for appropriate production and breeding strategies in Malawi? Cuvillier Verlag. Available at: https://cuvillier.de/uploads/preview/public_file/5584/3865373542.pdf

Geldenhuys, G., Muller, N., Frylinck, L. \& Hoffman, L.C., 2015. Post mortem rigor development in the Egyptian goose (Alopochen aegyptiacus) breast muscle (pectoralis): factors which may affect the tenderness. J. Sci. Food Agric. 96, 271-279. DOI: 10.1002/jsfa.7090

Grashorn, M., 2010. Research into poultry meat quality. Brit. Poult. Sci. 51 Suppl, 1, 60-67. DOI: 10.1080/00071668.2010.506761

Klaus G. Grunert, K.G.,Bredahl, L. \& Brunsø, K., 2004. Consumer perception of meat quality and implications for product development in the meat sector - a review. Meat Sci. 66, 259-272. doi:10.1016/S0309-1740(03)00130-X

Holcman, A., Vadnjal, R., Zlender, B. \& Stibilj, V., 2003. Chemical composition of chicken meat from free range and extensive indoor rearing. Arch. Geflügelk. 67(3), 120-124.

Hong, E.C., Heo, K.N., Kim, H.K., Kang, B.S., Kim, C.D., Choo, H.J., Choi, H.C., Mushtag, M.M.H., Purnin, R. \& Kim. J.H., 2014. Growth performance, carcass yield and meat quality of Korean native duck. J. Agric. Sci. Tech. A4, 7685.

Huda, A., Putra, A.A. \& Ahmad, R., 2011. Potential application of duck meat for development of processed meat products. Current Research in Poult. Sci. 1,1-11. DOI: 10.3923/crpsaj.2011.1.11

Huff-Lonergan, E., Parrish Jr., F.C. \& Robson, R.M., 1995. Effects of post-mortem aging time, animal age, and sex on degradation of titin and nebulin in bovine longissimus muscle. J. Anim. Sci. 73, 1064-1073.

Ismed, H.N. \& Ismail, N., 2013. Physicochemical analysis and mineral composition of duck meat (Peking, Muscovy and Local Java). Intern. J. Biol. Ecolog. Environ. Sci. 2(5), 2277-4394.

Keeton, J.T. \& Eddy, S., 2004. Chemical and physical characteristics of meat. In: W.K. Jensen, C. Devine, \& M. Dikeman (eds.), Encyclopedia of meat science. Elsevier, Oxford. pp. 210-218.

Khan, M.I., Lee. H.J., Kim, H.J., Young, H.I., Lee, H. \& Jo, C., 2016. Marination and physicochemical characteristics of vacuum-aged duck breast meat. Asian-Austra. J. Anim. Sci. 29(11), 1639-164. Available at: http://dx.doi.org/10.5713/ajas.15.1053

Kim H.K., Kang, B.S., Hwangbo, J., Kim, C.D., Heo, K.N., Choo, H.J., Park, D.S., Suh, O.S. \& Hong, E.C., 2012. The study on growth performance and carcass yield of meat-type Korean native ducks. Korean J. Poult. Sci. 39, 45-52.

Kirmizibayrak, T., Önk, K., Ekiz, B., Yalcintan, H., Yilmaz, A., Yazici, K. \& Altinel, A., 2011. Effects of age and sex on meat quality of Turkish Native Geese raised under a free-range system. Kafkas Univ Vet Fak Derg, 17, 817-23.

Kondjoyan, A., Oillic, S., Portanguen, S. \& Gros, J.B., 2013. Combined heat transfer and kinetic models to predict cooking loss during heat treatment of beef meat. Meat Sci. 95(2), 336-344.

Kwon, H.J., Choo, Y.K., Choi, Y.I., Kim, E.J., Kim, H.K., ..., An, B. K., 2014. Carcass characteristics and meat quality of Korean Native Ducks and commercial meat-type ducks raised under same feeding and rearing conditions. AsianAustra. J. Anim. Sci. 27(11), 1638-1643. http://doi.org/10.5713/ajas.2014.14191

Lacin, E., Aksu, M.I., Macit, M., Yildiz, A., Karaoglu, M., Esenbuga, N. \& Yoruk, M.A., 2008. Effects of different raising systems on colour and quality characteristics of Turkish Pekin duck meats. S. Afr. J. Anim. Sci. 38, 217-223.

Li, Y., Luo, C., Wang, J. \& Guo, F., 2017. Effects of different raising systems on growth performance, carcass, and meat quality of medium-growing chickens. J. Appl. Anim. Res. 45(1), 326-330. DOI: 10.1080/09712119.2016.1190735

Liao, C.C., Chang, Y.S., Yang, S.Y. \& Chou, R.G.R., 2016: Post-mortem proteolysis and tenderisation are more rapid and extensive in female duck breast muscle. Br. Poult. Sci. 57(6), 734-739. DOI: 10.1080/00071668.2016.1209736

López, K.P., Schilling, M.W. \& Corzo, A., 2011. Broiler genetic strain and sex effects on meat characteristics. Poult. Sci. 90, 1105-1111. https://doi.org/10.3382/ps.2010-01154

Lorenzo, J.M., Purriños, L., Temperán, S., Bermúdez, R., Tallón, S. \& Franco, D., 2011. Physicochemical and nutritional composition of dry-cured duck breast. Poult. Sci. 90(4), 931-940.

Mazanowski, A., Kisiel, T. \& Gornowicz, E., 2003. Carcass quality, meat traits and chemical composition of meat in ducks of paternal strains A44 and A55. Animal Science Papers and Reports, Institute of Genetics and Animal Breeding, Poland, 21: 251-263.

Mallia, G.J., Barbut, S., Vaillancourt, J.P, Martin, S.W. \& McEwen, S.A., 2000. A dark firm dry-like condition in turkeys condemned for cyanosis. Poult. Sci. 79, 281-285.

McDonald, P., Edwards, R.A., Greenhalgh, J.F.D., Morgan, C.A., Sinclair, L.A. \& Wilkinson, R.G., 2010. Animal nutrition. 7th edition. Pearson Education Ltd., Edinburgh, Scotland. pp. 103-130. 
Mennecke, B.E., Townsend, A.M., Hayes, D.J. \& Lonergan, S.M., 2007. A study of factors that influence consumer attitudes toward beef products using the conjoint market analysis tool. J. Anim. Sci. 85, 2639-2659.

Michalczuk, M., Lukasiewicz, M., Zdanowska-Sasiadek, Z. \& Niemiec. J., 2014. Comparison of selected quality attributes of chicken meat as affected by rearing systems. Pol. J. Food Nutr. Sci. 64(2), 121-126.

Mussah, S.R. \& Phoya, R.K.D., 2017. Determination of age at slaughter on meat quality characteristics for indigenous Malawian spotted (kawangi) chickens. Livestock Research for Rural Development volume 29, article \#53. http://www.Irrd.org//rrd29/3/muss29053.html. Accessed 9 March 2017

Musundire, M.T., Halimani, T.E. \& Chimonyo, M., 2017. Physical and chemical properties of meat from scavenging chickens and helmeted guinea fowls in response to age and sex. Br. Poult. Sci. 58(4), 390396. DOI: $10.1080 / 00071668.2017 .1313961$

Mutibvu, T., Chimonyo, M. \& Halimani, T.E., 2017. Physiological responses of slow-growing chickens under diurnally cycling temperature in a hot environment. Braz. J. Poult. Sci. 19(4), 567-576. https://dx.doi.org/10.1590/1806-90612017-0485

National Research Council, 1994. Nutrient requirements of poultry. 9th revised edition. National Academy Press, Washington, DC, USA. pp. 42-44.

Njunga, G.R., Levison, M.P., Makhambera, A.K. \& Peter, S., 2010. Child labour in livestock production in Malawi. Ministry of Gender, Child and Labour, Malawi.

Pathare, P.B. \& Roskilly, A.P., 2016. Quality and energy evaluation in meat cooking. Food Eng. Rev. 8, 435-447. DOI: 10.1007/s12393-016-9143-5.

Piao, M.Y., Jo, C., Kim, H.J., Lee, H.J. Kim, H.J., Ko, J.Y. \& Baik, M., 2015. Comparison of carcass and sensory traits and free amino acid contents among quality grades in loin and rump of Korean cattle steer. Asian-Austra. J. Anim. Sci. 28,1629-1640.

Ponte, P.I.P., Prates, J.A.M., Crespo, J.P., Crespo, D.G., Mourão, J.L., ..., Fontes, C.M.G.A., 2008. Restricting the intake of a cereal-based feed in free-range-pastured poultry: Effects on performance and meat quality. Poult. Sci. 87, 20322042.

Pripwai, N., Pattanawong, W., Punyatong, M. \& Teltathum, T., 2014. Carcass characteristics and meat quality of Thai inheritance chickens. J. Agric. Sci. 6(2), 182-188. Doi: 10.5539/jas.v6n2p182

Rahman, M.M., Khan, M.J. \& Chowdhury, S.D., 2014. Effect of feed supplementation on chemical composition of meat of three genotypes of scavenging ducklings in coastal areas of Bangladesh. Bang. J. Anim. Sci., 43, 25-29. DOI: http://dx.doi.org/10.3329/bjas.v43i1.19381

Rahman, A., Rehman, M., Gadahi, J.A., Samo, M.T., Bhutto, B., Ullah, Q. \& Khaskeli, M., 2012. Studies on the evaluation of moisture and ash content in Kamori, Pateri and Tapri goat meat. International J. Agro. Vet. and Med. Sci. 6(1), 62-68. DOI: 10.5455/ijavms.136

Raj, A.B.M., Richardson, R.I., Wilkins, L.J. \& Wotton, S.B., 1998. Carcass and meat quality in ducks killed with either gas mixture or an electric current under commercial processing condition. Br. Poult. Sci. 39, 404-407.

Ramadhan, K., Huda, N. \& Ahmad, R., 2010. Duck meat utilization and the application of surimi-like material in further processed meat products. J. Biol. Sci., 10, 405-410. DOI: 10.3923/jbs.2010.405.410

Ronald, B.P., Ryszard, A. \& William, E.C., 2006. Nutritional characteristics of emu (Dromaius novaeholandiae) meat and its value-added products. J. Food Chem. 193-202.

Singh, V.P. \& Pathak, V., 2017. Physico-chemical, colour and textural characteristics of Cobb-400, Vanajara, Aseel and Kadaknath meat. International J. Livest. Res. 7(11), 98-106. DOI: 10.5455/ijlr.20170801054850

Smith, D.P., Fletcher, D.L., Buhr, R.J. \& Beyer, R.S., 1993. Pekin ducklings and broiler chicken pectoralis muscle structure and composition. Poult. Sci. 72, 202-208.

Smith, D.P., Northcutt, J.K., Sigmon, C.S. \& Parisi, M.A., 2015. Effect of sex, bird size and marination on duck breast meat quality. Int. J. Poult. Sci. 14(4), 191-195.

Stankov. I.K., Todorov, N.A., Mitev, J.E. \& Miteva, T.M., 2002. Study on some qualitative features of meat from young goat of Bulgarian breeds and cross-breeds of goats slaughtered at various ages. Asian-Austra. J. Anim. Sci. 15, 283-289.

Tougan, P.U., Dahouda, M., Salifou, C.F.A., Ahounou, S.G.A., Kpodekon, M.T., Mensah, G.A., Thewis, A. \& Karim, I.Y.A., 2013. Conversion of chicken muscle to meat and factors affecting chicken meat quality: A review. International J. Agron. Agric. Res. 3(8), 1-20.

Uhlí̌ová, U., Tưmová, E., Chodová, D., Vlčková, J., Ketta, M., Volek, Z. \& Skřivanová, V., 2018. The effect of age, genotype and sex on carcass traits, meat quality and sensory attributes of geese. Asian-Austral. J. Anim. Sci. 31, 421-428.

USDA 2015. National nutrient database for standard reference, Release 28. http://www.ars.usda.gov/ba/bhnrc/ndl

Van Laack, R.L.J.M., Liu, C.H., Smith, M.O. \& Loveday, H.D., 2000. Characteristics of pale, soft, and exudative broiler breast meat. Poult. Sci. 79, 1057-1061.

Wang, K.H., Shi, S.R., Dou, T.C. \& Sun, H.J., 2009. Effect of a free-range raising system on growth performance, carcass yield, and meat quality of slow-growing chicken. Poult. Sci. 88, 2219-2223.

Wattanachant, S., 2008. Factors affecting the quality characteristics of Thai indigenous chickens. Suranaree J. Sci. Technol. 15, 317-322

Webb, E.C. \& Erasmus, L.J., 2013. The effect of production system and management practices on the quality of meat products from ruminant livestock. S. Afr. J. Anim. Sci. 43, 413-423.

Witkiewicz K., 2000. Zoometric measurements, slaughter value and chemical composition of the breast muscle in two strains of ducks of Pekin type. In Polish with English summary. Roczniki Akademii Rolniczej w Poznaniu 330, 231240. 
Woloszyn J., Ksiazkiewicz J., Orkusz A., Skrabka-Blotnicka T., Biernat J. \& Kisiel T., 2002. Preliminary evaluation of chemical composition of duck's muscles from two Polish conservative flocks. Proc. 48th International Congress of Meat Sci. Tech. 25-30 August 2002, Rome, Italy. Pp. 374-375.

Yang, H.S., Choi, S.G., Jeon, J.T., Park, G.B. and Joo, S.T., 2007. Textural and sensory properties of low fat pork sausages with added hydrated oatmeal and tofu as texture modifying agents. Meat Sci. 75, 283-289

Yarmand, M.S., Nikmaram, P., Emam Djomeh, Z. \& Homayouni, A., 2013. Microstructural and mechanical properties of camel longissimus dorsi muscle during roasting, braising and microwave heating. Meat Sci. 95 (2), 419-42

Zhang, Y.Y., Zan, L.S., Wang, H.B. Xin, Y.P., Adoligbe, C.M. \& Ujan, J.A., 2010. Effect of sex on meat quality characteristics of Qinchuan cattle. Afric. J. of Biotech. 9(28), 4504-4509.

Zhou, C.K., Ohtani, S. \& Tanaka, K.I., 2000. Carcass composition, parts proportion and fat deposition of meat-type growing ducks. Japanese J. Poul. Sci. 37, 357-354. 